\title{
Originalartikel
}

\section{Telemedicin: Et maktperspektiv}

\author{
Kari Dyb \& Hege K. Andreassen
}

Nasjonalt senter for samhandling og telemedisin (NST) i Tromsø

kari.dyb@telemed.no

hege.andreassen@telemed.no

Dyb, K \& Andreassen, H.K. (2014). Telemedisin: et maktperspektiv, Tidsskrift for Forskning i Sygdom og Samfund, nr. 21, 37-55

Til tross for betydelige statlige investeringer over flere år, er ikke telemedisin en etablert behandlingsform i norsk helsevesen. Lav utbredelse forklares ofte med at leger og andre helseprofesjonelle fungerer som portvakter. Etter vår mening er det behov for å heve blikket og supplere forklaringene på individnivå. I denne artikkelen presenterer vi en empirisk analyse inspirert av Bourdieus maktperspektiv. Vi har brukt intervju, observasjons og dokumentmateriale fra to empiriske case, teleslag og teledermatologi. I begge casene var legene positive til bruk av telemedisin, men løsningene ble lite brukt. Analysen fär frem hoordan telemedisin er mer enn nye verktøy for klinkerne, og faktisk trigger diskusjoner om selve kjernen $i$ helsefeltets autonomi; spørsmålet om hoa som er den riktige behandling. Vi konkluderer med at mottagelsen av telemedisin $i$ klinisk praksis må forstås $i$ lys av pågående maktkamper $i$ helsefeltet, mellom statlige styringsinteresser på den ene siden og profesjonell autonomi på den andre.

\section{Telemedicine; power disruptions in health care}

Although the development of telemedicine has been a priority in Norwegian public health care for over 20 years, only a limited number of applications have been established as routine services. Dominant explanations of slow diffusion points to clinicians and their role as gatekeepers. We argue there is a need to look beyond the ubiquitous accounts of individual influences, and include power structures in the analysis of telemedicine diffusion. In this paper, we present an empirical analysis inspired by Bourdieu's conceptual framework. The 
data consist of interviews, observations, and public- and project documents from two case studies; telestroke and teledermatology. In both cases, the clinicians were positive and involved in the implementation of telemedicine. Nevertheless, the services were not developed into routine practice; in fact, they were rarely used. Telemedicine touches upon the core value of health care activity: how to define the best patient treatment. The paper argues telemedicine might disrupt and be disrupted by existing power struggles in the health care sector. We conclude that slow diffusion of telemedicine should be understood in light of ongoing negotiations and power struggles between state regulatory powers on the one hand and health professional autonomy on the other.

\section{Innledning:}

Spørsmålet om hvorfor spredningen av telemedisin tar så lang tid blir drøftet i media, faglitteraturen og blant praktikere (KS, 2008; Schreurs, 2012; Wyatt \& Sullivan, 2005). Telemedisin har vært et satsingsområde i norsk helsesektor siden tidlig på 1990 tallet. Den første tiden var preget av optimisme, og potensielle besparelser og kvalitetsforbedringer fikk mye oppmerksomhet. I dag er de optimistiske forventningene akkompagnert av kritiske røster. Kritikerne legger vekt på at få løsninger er i bruk i daglig klinisk praksis, og spør hvorfor ikke flere telemedisinløsninger er standardiserte og innført som rutinebehandling i stor skala.

I dagsaktuelle telemedisindebatter stilles altså spørsmålet om hvordan og hvorfor telemedisin lykkes eller mislykkes (Starling \& Foley, 2006; Whitten, Holtz, \& Nguyen, 2010; Zanaboni \& Wootton, 2012). Blant dem som arbeider med å utvikle og drifte telemedisin har det å få legene "med på laget" vært et hovedfokus: "I hear from many people that the biggest challenges to getting their telehealth programs running is getting physicians on board" skriver for eksempel redaktøren på nettstedet "Hands on telehealth" (Desai, 2014). Mange undersøkelser har vært gjort for å kartlegge leger og pasienters holdninger til telemedisin (Dünnebeil, Sunyaev, Blohm, Leimeister, \& Krcmar, 2012; Walter \& Lopez, 2008; Whitten \& Holtz, 2008; Ziefle, Klack, Wilkowska, \& Holzinger, 2013).

I denne artikkelen belyser vi innføring av telemedisin i helsesektoren fra en annen vinkel. Til tross for at en ønsket politisk endring, telemedisin i pasientbehandling, har blitt fulgt av store statlige ressurser og et mangfold av tiltak over flere år er telemedisin lite brukt. En slik systematisk og vedvarende motstand mot en statlig ønsket endring er sosiologisk interessant. Motkreftene indikerer at det 
er på tide å løfte blikket fra individnivå, til å kartlegge hvordan fenomenet telemedisin berører og berøres av overordnede maktstrukturer $i$ helsevesenet.

Vår målsetning er å kontekstualisere fenomenet telemedisin i sin politiske samtid. Vi undersøker om utfordringene med å spre telemedisin i klinisk praksis kan sees i sammenheng med overordnede maktstrukturer og -spenninger i sektoren. Gjennom en Bourdieuinspirert feltanalyse ønsker vi å nyansere bildet av hva som skjer når telemedisin introduseres i helsevesenet. Det handler om mer enn møter mellom "moderne" teknologi og "tradisjonelle" klinikere. Vi tar utgangspunkt i to empiriske case, teledermatologi og teleslag (engelsk "telestroke"). Casene er strategisk valgt. Begge er eksempler på telemedisin som er lite brukt, men der det ikke er eksplisitt motstand blant legene (på individnivå). I våre case var legene med på å innføre telemedisin.

\section{To empiriske cases}

Telemedisin forstår vi som "undersøkelse, overvåkning, behandling og administrasjon av pasienter og opplæring av pasienter og personale via systemer som gir umiddelbar tilgang til ekspertise og pasientinformasjon uavhengig av hvor pasienten eller relevant informasjon er geografisk plassert" (NST Web, 2014).

\section{Case 1: Teledermatologi}

I Norge ble teledermatologi, telemedisin til behandling av hud, første gang prøvd ut for ca. 20 år siden. De første løsningene var stillbilder og videokonferanse i samarbeidet mellom spesialistavdelinger på sykehus og lokale leger. Kort oppsummert ser vi at siden de første utprøvingene på slutten av 80-tallet og frem til i dag, har bruken av gått gjennom en fase med vekst, for så å avta igjen. Vår casestudie inkluderer flere primærleger og ett sykehus. Forrige videokonferansesending mellom sykehuset og en primærlege var i 2011. Det har heller ikke vært mye bruk av stillbilder de siste årene. Tilbudet er ikke formelt lagt ned. Det er ikke tatt noen beslutning om slutte å ta imot stillbildehenvisninger eller stille på videokonferansekonsultasjoner. Sykehuset har tvert imot en uttalt policy om å være "Telemedisinsykehuset", og jobber aktivt for å få flere avdelinger til å ta i bruk videokonferanseløsninger i samarbeid med lokale helsetjenester.

Vi ble nysgjerrige på historien til teledermatologi, og spesielt hvordan veksten og nedgangen i bruk av stillbildehenvisninger og videokonferansekonsultasjoner 
kan forklares. Erfaringene fra de første utprøvingene var positive, dokumentene fra den første tiden uttrykker optimisme og forventninger i forhold til økonomiske og sosiale besparelser (Helsedepartementet, 1999). Særlig er det at pasientene nå slipper reisen til sykehuset fremhevet som en stor fordel for alle parter (Moseng, 2000). I en evaluering av ulike telemedisinløsninger fra 2005 finner vi at teledermatologi ble regnet som en relativt moden tjeneste i Norge (Norum et al., 2007). Sammen med øre - nese-hals og elektronisk overføring av hjertelyd av barn, ble teledermatologi forsøkt satt i rutinedrift i hele den nordlige landsdelen rundt årtusenskiftet. I en større nasjonal satsing i perioden 1999 - 2002 fikk om lag 180 nord norske legekontorer tilbud om utstyr og opplæring i bruk. Satsingen var finansiert av det norske Sosial- og helsedirektoratet. I rapporten fra denne satsingen kan vi lese at 22 allmennlegekontorer takket ja og slik fikk muligheten til å bruke teledermatologi (Larsen, Gjerdrum, Obstfelder, \& Lundvoll Nilsen, 2003) Når vi leser dokumenter som omhandler teledermatologi fra 90- og tidlig 2000 tall ser altså fremtiden for slike løsninger lys ut. Likevel er de lite brukt i dag.

\section{Case 2: Teleslag}

Teleslag, eller det som på engelsk kalles «telestroke» er telemedisin til behandling av hjerneslag, og brukes om telemedisinske tjenester som tilbyr hjerneslagbehandling over distanse. Rasjonale er å tilby hjerneslagpasienter ved små lokalsykehus tilgang til spesialistkompetanse fra en stor slagenhet eller slagsentra ved et større sykehus (Helsedirektoratet, 2010). Ved bruk av teleslag er det lokalt helsepersonell som utøver selve behandlingen, men med online støtte og veiledning fra en slagspesialist. Spesialisten kan se, snakke og undersøke pasienten via videokonferanse. Hun har også online tilgang til nødvendige radiologibilder, og noen ganger også til pasientens journal.

Hjerneslag er den tredje hyppigste dødsårsaken i Norge, og den vanligste årsaken til alvorlig funksjonshemming hos voksne. Årlig insidens av hjerneslag i Norge er ca. tre per 1.000. Ved akutt hjerneinfarkt kan det være indikasjon for å gi blodpropp-oppløsende behandling, såkalt trombolyse. Trombolyse må gis så raskt som mulig, og senest inne 4 timer etter symptomdebut. Tanken er at teleslag skal øke tilgjengeligheten til trombolytisk behandling ved at det gis rask og riktig beslutningsstøtte til mindre sykehus som mangler erfaring og kompetanse.

Internasjonalt er teleslag er en veletablert og godt dokumentert telemedisinsk løsning. Flere studier viser klar klinisk effekt (Audebert, 2006; Handschu et al., 2008; Meyer et al., 2008). Løsningen vi har studert ble initiert i kjølvannet av vul- 
kanhendelsen på Island. Et vulkanutbrudd lammet flytrafikken i Nord Norge, og synliggjorde hvor sårbart akuttilbudet i helseregionen er uten luftambulanse. Regionen er stor, og dekker omtrent halve Norge. Telemedisin ble innført ved to lokalsykehus, og koblet opp til det største sykehuset i fylket i 2010. De regionale helsemyndigheter, Helse Nord RHF, finansierte innføringen.

\section{Metode}

Det empiriske materialet vi refererer til i denne artikkelen ble samlet inn i 2011 og 2012.

\section{Forskernes posisjonering i feltet}

Interessen for å studere telemedisin i lys av et maktperspektiv bygger på mer enn 10 års erfaring fra telemedisinmiljøet i Norge. Begge forfatterne er sosiologer og forskere ved den nasjonale kompetansetjenesten for telemedisin i Norge, Nasjonalt senter for telemedisin (NST). Det å være samfunnsforsker i en tverrfaglig forsknings- og utviklingsinstitusjon har gitt oss en unik mulighet til å følge arbeidet med å utvikle og spre telemedisin i Norge på nært hold. De siste 10 årene har vi studert flere konkrete telemedisinprosjekter og fulgt med på hvilke forventinger som formuleres av ulike aktører; helsemyndigheter, forsknings- og utviklingsmiljøet innen telemedisin, og helseprofesjonelle. Vi observerer at det er en overvekt av analyser og forklaringer på individnivå i dagens telemedisindebatter, både i helsepolitikken og blant praktikere.

\section{Utvalg}

Casene våre er strategisk valgt (Tjora, 2010) for å belyse telemedisin fra et maktperspektiv. Begge er eksempler på løsninger som ble innført i samarbeid med de involverte legene, men der telemedisin likevel er lite brukt. Studien som presenteres her bygger på tidligere innsamlet kvalitativt materiale (intervjuer og feltobservasjoner). Datamaterialet er samlet inn av forfatterne med formål å belyse aktørenes erfaringer og refleksjoner rundt innføring av telemedisin. 


\section{Dataproduksjon}

Studien baserer seg på flere kilder: intervju, feltnotater og dokumenter. Forfatterne har hatt ansvar for innsamlingen av materiale i ett case hver, som observatører og intervjuere. Søk etter dokumenter er gjort i fellesskap.

I begge casene ble det gjort intervjuer. Fra teledermatologi har vi intervjuet 19 aktører som har vært involvert i løpet av de siste 20 år: 6 leger (fra ledelse og klinisk praksis), 3 leverandører av IKT systemer, 3 helsebyråkrater og 8 prosjektdeltakere fra ulike teledermatologiprosjekter. Intervjuene var fokusert mot historien til teledermatologi spesielt og telemedisin generelt i Norge, og informantene ble bedt om å kommentere påstanden om lav utbredelse. Fra teleslag har vi til sammen 20 intervjuer. Intervjuene ble gjort på arbeidsplassene. De var i hovedsak med leger, men vi har også intervjuet de sykepleierne som var mest involvert $\mathrm{i}$ hjerneslagbehandlingen, teknologen som var ansvarlig for å koble opp løsningen, og fire prosjektarbeidere som var med å igangsette tjenesten. Intervjuene tok utgangspunkt i informantenes erfaringer med teleslag, og oppfordret til refleksjon omkring mulighetene for å oppnå de samme gevinstene i Nord-Norge som er dokumentert internasjonalt. Intervjuene var semistrukturerte, de ble tatt opp og transkribert, og varte fra $30 \mathrm{~min}$ til 2 timer.

I caset teleslag ble det gjort feltarbeid ved tre sykehus. Feltarbeidene varte til sammen en uke. Tre forskere, en sosiolog, en informatiker og en pedagog observerte teknologisk og organisatorisk infrastruktur, og kartla rutiner for slagbehandling. Det ble tatt feltnotater.

I tillegg har vi inkludert 18 skrevne dokumenter i materialet. Disse gjenspeiler myndighetenes offisielle syn på telemedisin (offentlige dokumenter) og dokumenterer forsknings- og utviklingsarbeidet innen teledermatologi og teleslag (evalueringsrapporter, prosjektplaner og vitenskapelige artikler).

\section{Teori og analytisk tilnærming}

Vårt teoretiske inntak til å studere telemedisin og makt er inspirert av Bourdieus maktteori. Vi ønsker å supplere eksisterende litteratur. Samfunnsvitenskapelige studier av telemedisin har i stor grad vært influert av Science Technology Studies (STS). Forfattere som bygger på STS har gjennom detaljerte case-studier vist hvordan medisin og helsefag er preget av en kompleksitet og mangesidighet som er utfordrende å bygge inn i IKT løsninger (Langstrup Nielsen, 2003, 2003). Videre 
har perspektivet åpnet for nye diskusjoner om visjonene for IT-implementering i helsevesenet (Jensen \& Winthereik, 2002) og om IKT og pasientidentiteter (Mort, Finch, \& May, 2009). Samtidig som vi anerkjenner STS-analyser som en viktig ressurs, er vi enige i noe av kritikken mot denne teoretiske retningen. Donna Haraway (2004) har påpekt at et snevert empirisk fokus på mikronivå kan bidra til å overse vesentlige maktforskjeller. Halford og Savage (2010) argumenterer i tråd med dette når de kombinerer STS med Bourdieu i studier av sosial ulikhet. For oss er det viktig å inkludere maktstrukturer for å forstå og forklare mottakelsen av telemedisin i dagens helsevesen. Så langt vi kjenner til, er maktstrukturene i helsesektoren, og hvordan disse berører og berøres av telemedisin lite beskrevet i faglitteraturen. Selv om der finnes unntak, som Carl May's (2013) "Normalization process theory" og Obstfelder, Lotherington og Johanessens (2013) studie av helse-IKT i et governmentalityperspektiv, mener vi det er behov for ett sterkere og mer eksplisitt fokus på makt.

Vi har gått til Bourdieu fordi han, til forskjell fra andre konstruktivistiske maktteoretikere som Foucault og Goffman, har et begrep om objektive strukturer. Dette mener vi er sentralt i studier av helsesektoren, som preges av vedvarende hierarkier. Bourdieu er kjent som konfliktteoretiker. Hans sosiologiske teorier har vært viktige teoretisk verktøy i analyser av statens rolle som maktutøver de siste 40 årene (Mik-Meyer \& Villadsen, 2007). I vårt empiriske materiale har staten, representert ved nasjonale og regionale helsemyndigheter, en sentral posisjon som pådriver for telemedisin. En annen grunn til at tilnærmingen er velegnet for vår studie er at Bourdieus analyseapparat holder fast ved viktigheten av konkrete, praksisnære studier, samtidig som han kontinuerlig viser hvordan praksis relaterer seg til objektive, registrerbare, strukturelle vilkår, som ofte ligger utenfor det enkelte individs bevissthet (Mik-Meyer \& Villadsen 2007: s 69).

\section{Felt, kapital og habitus}

Ifølge Bourdieu er det nødvendig med en beskrivelse av hele det sosiale rom der samhandling, sosial utveksling og hendelser foregår (Thomson, 2012). Dette er bakgrunnen for hans analytiske begrep felt. Feltbegrepet er ikke et enten eller konsept. Sosiale felt har ingen fast eksistens; de oppstår, endrer grenser og forsvinner som følge av historiske endringer (Bourdieu \& Wacquant, 1992). Innen et felt har aktørene ulike posisjoner som er bestemt av mengden en aktør besitter av den feltspesifikke kapitalen (Bourdieu, 1995). Bourdieu definerer rett og slett et felt 
som den arena som oppstår der det har utkrystallisert seg en særegen kapitaltype (Bourdieu \& Wacquant, 1992).

Bourdieu bruker ikke kapitalbegrepet for å understreke viktigheten av økonomiske ressurser. Tvert imot bruker han det for å imøtegå økonomisk reduksjonisme. Ved å poengtere at der finnes flere former for kapital enn den økonomiske får han frem at det er flere typer av ressurser som er viktige i det sosiale liv.

Begrepet habitus forbinder aktør og struktur i Bourdieu teoretiske tilnærming (Bourdieu, 1999: 56). Objektive strukturer internaliseres kroppslig og former aktørenes muligheter for handling. I kraft av forskjeller i utdanning, kjønn, klasse, geografisk tilhørighet, økonomiske vilkår osv. har mennesker forskjellig habitus, det vil si handlingsskjemaer eller systemer av varige overførbare disposisjoner (ibid).

Basert i Bourdieus terminologi kan vi snakke om helsevesenet som et eget felt. Feltet er befolket av aktører som sitter i posisjoner med objektive relasjoner til hverandre, for eksempel i et stillingshierarki eller i et arbeidsgiver/ ansattforhold. For vår studie av helsefeltet er Bourdieus begrepsapparat og analytiske tilnærming interessant fordi den kan hjelpe oss å løfte blikket og studere overordnede maktstrukturer uten at vi mister enkeltaktørene av syne. Videre er Bourdieu konfliktteoretiker, hans tilnærming til sosialt liv er at dette til enhver tid holdes i ånde av konflikter og spenninger. Det er nettopp spenninger, nærmere bestemt rundt innføring av ny teknologi, som er utgangspunktet for vår empiriske undersøkelse. Vi ønsker å forstå strukturelle motkrefter mot en statlig ønsket endring.

\section{Analyse}

Det er tre element som er nødvendige for å gjøre en feltanalyse (Bourdieu og Wacquant, 1991: 90). Det første er å analysere hvilken posisjon det aktuelle feltet, helse i vårt tilfelle, har i forhold til det statlige maktfeltet. Det andre er å etablere en objektiv struktur av relasjoner mellom posisjoner som er inntatt av agenter eller institusjoner som konkurrerer med hverandre innenfor feltet. Det tredje elementet er en analyse av habitus hos agentene. Vår studie av telemedisin og makt er inspirert av en feltanalytiske tilnærming, samtidig som vi starter i empirien, snarere enn i Bourdieus teoretiske begreper. Analysen tar utgangspunkt i Mik Meyer og Villadsens (2007) tilnærming til felt, som et rom av posisjoner hvor det foregår en kamp mellom nyankomne og dominante om de fundamentale interes- 
sene som utgjør feltets eksistens. I helsefeltet er definisjonen av den gode og riktige pasientbehandling en slik fundamental interesse.

\section{Helsefeltets posisjon i forhold til det statlige maktfelt}

I Norge er helsefeltet er sentralt plassert i det overordnede statlige maktfeltet. Den norske helsetjenesten er i all hovedsak offentlig. Det finnes enkelte private tilbud, spesielt i de store byene, men disse er relativt få. Regjeringen har et eget Helse- og omsorgsdepartement som "har det overordnede ansvaret for at befolkningen fär gode og likeverdige helse- og omsorgstjenester, uavhengig av blant annet bosted og økonomi. Departementet styrer helse- og omsorgstjenesten gjennom et omfattende lovverk, årlige bevilgninger og ved hjelp av statlige etater, virksomheter og foretak" (Regjeringen, 2014). Helse- og omsorgsministeren er departementets øverste leder. Norske offentlige sykehus er organisert som statseide helseforetak (HF), administrert gjennom fire regionale helseforetak (RHF). Helse og omsorgsdepartementet delegerer ansvar for allmennlegetilbudet til kommunene. Ansvaret omfatter organisering av fastlegeordning, og at personer som ønsker det får plass på en fastlegeliste (pasient og brukerrettighetsloven $\S 2-1 \mathrm{c}$ og forskrift om pasient- og brukerrettigheter i fastlegeordningen §2.)

\section{Stat, helsefelt og telemedisin}

I vår lesing av norske offentlige dokumenter finner vi at nye IKT-løsninger, som telemedisin, blir fremstilt som et gode for helsefeltet. På departementets websider kan vi lese helseministeren uttale seg; "Bedre IKT løsninger er en forutsetning for å lykkes med å skape pasientenes helsevesen og kommunikasjon" (Regjeringen, 2014). Bedre IKT løsninger, for eksempel telemedisin, blir også anbefalt $i$ "Samhandlingsreformen"(HOD, 2008: Stortingsmelding nr 49), og materialiseres som egen strategi: «Samspill 2.0, Nasjonal strategi for elektronisk samhandling i helse- og omsorgssektoren». Når det gjelder slagbehandling spesielt, fant vi at Helsedirektoratet (2010) anbefaler telemedisinske nettverk som et viktig virkemiddel for at mindre sykehus kan gi avansert slagbehandling. Vår fortolkning er at bedre IKT-løsninger er et objektivt strukturelt forhold, som det ikke settes spørsmål ved. Om en skal bruke IKT tas ikke opp til debatt, spørsmålet er hvordan IKT best kan brukes i helsefeltet. 


\section{Case 1: Telemedisin berører maktstrukturene i feltet}

For å analysere caset teledermatologi fant vi det nyttig å se på de objektive relasjonene mellom tre hovedaktører; eier (staten ved helsedepartementet og regionale helseforetak), kliniske praktikere (leger og andre helseprofesjonelle yrkesutøvere) og de nyankomne IT-utviklere, leverandører og driftere. Staten er eier og har makt over feltet, og delegerer ansvar til andre aktører i regional og lokal helseadministrasjon og ledelse. Eier har selvsagt stor innflytelse på helsefeltets mål. Kliniske praktikere, og særlig legene, har sterke posisjoner i feltet på bakgrunn av sin kulturelle kapital, helsefaglig og medisinsk utdanning. Det er denne utdanningen som gir evne til å helbrede og redde liv. De som har slik utdanning får posisjoner der de kan være med å definere kjerneverdien i helsefeltet; hva som til enhver tid er den riktige behandling. Ut fra de objektive relasjoner mellom eier; staten, og ansatte med formell medisinsk utdanning utgår helsefeltets legitimitet og spesifikke autoritet.

Teledermatologi er mindre brukt i dag enn for ti år siden. Ingen av våre informanter kunne presentere oss for en enkel kausalforklaring, eller en klar årsak til at teledermatologi ikke er i rutinedrift. En distriktslege understreket at han gjerne skulle brukt stillbilder i samhandling med spesialistene på sykehuset. På direkte spørsmål visse han ikke hvorfor dette ikke var i bruk lenger:

Distriktslege (DL): det var synd at det tilbudet ble borte. Det skulle jeg gjerne sett stablet på bena igjen.

Intervjuer (I): Var det [spesialisten] som ikke stilte opp lenger?

DL: Ja, jeg forsto det, jeg gikk ikke inn i materien der, det kan kanskje ha vært andre grunner også, det, uten at jeg har oversikt over det, men i alle fall så ble det borte. Og det hadde også noe med å gjøre at [...] det ble ikke noe videreutvikling på den datatekniske biten.

Sykehusspesialistene uttrykte heller ikke å ha god oversikt over hva som har skjedd, eller hva som eventuelt måtte til for å få bruken i gang igjen:

Spesialist (SL): Det var litt spredt og tilfeldig [hvilke fastleger som brukte stillbilde].

Og så kom de og så forsvant de.

I: Så det var personavhengig? 
SL: Personavhengig ja. Så det var ikke noe enhetlig system, og i tillegg da, så ble det krøll i hele stillbildesystemet. Det var borte en stund. Det var noe driftsfeil og det siste jeg hørte om det da var at det nå var så dyrt å drive at... Det var astronomiske summer bare for å ha det gående på noen få pasienter.

I: Dyrt for hvem?

SL: Dyrt for sykehuset. Vi måtte betale.

I: Og nå er det slik at det ikke finnes et tilbud da, faktisk.

SL: Det var det siste jeg hørte. I følge disse på IT avdelingen så var det noen enorme summer som går på dette med årlige avgifter også videre. Det ble helt bak mål for å se på noen få pasienter pr. år. For å se på noen få pasienter pr. uke.

\section{I: IT avdelingen her på sykehuset?}

SL: Jaaa jeg husker ikke. Via Helpdesk så får vi tak i det.

Vi ser at verken distriktslegen eller sykehusspesialisten er negative til å bruke teledermatologi. De er tvert i mot positive, og forklarer nedgangen i bruk med faktorer som ligger utenfor deres kontroll. Legenes holdninger fremstår ikke som en barriere for bruk i vår empiri fra teledermatologi. Evalueringer har også vist stor grad av pasienttilfredshet (Moseng, 2000). Legene snakker om teknologiske utfordringer som et problem. Videre ser vi, av sitatene, at dette er et problem de ikke har oversikt over, og heller ikke kompetanse til å løse. De snakker i runde vendinger om "den datatekniske biten", "noe driftsfeil", og "disse på IT". Dette fortolker vi til at legene har begrenset tilgang til en viktig ressurs, nemlig den tekniske oversikt, innsikt og kunnskap som er nødvendig for "å stable dette på beina igjen".

I et helsevesen der telemedisin er del av tilbudet er teknisk kompetanse nyttig. Vi tenker på denne kompetansen som teknisk kapital. Bourdieu (2005) bruker begrepet teknisk kapital som en underkategori av kulturell kapital. Når vi forstår den tekniske kompetansen som en form for kapital, ser vi at den er ulikt fordelt mellom helsevesenets aktører. Sykehuslegen vi har referert ovenfor forteller at han har fått beskjed fra IT om at teledermatologi er for dyrt å drifte for sykehuset, "det var det siste han hørte". I praksis vil det si at noen andre enn legene og den formelle sykehusledelsen sitter i en posisjon der de kan influere hvilke tjenester sykehuset skal tilby. "Disse på IT" deltar i å definere hva som er den riktige behandling. Dette er en endring fra tidligere. Nye posisjoner er oppstått. I det norske sykehussyste- 
met kan "Disse på IT" vise til minst to ulike aktører; det enkelte sykehuset egen ITavdeling/ IKT-forvaltning eller det regionale helseforetakets IKT-driftsleverandør. Videre er det slik at disse aktørene samarbeider med hverandre, med private leverandører av helsetjenestesystemer (for eksempel journalleverandører), og med Nasjonalt senter for telemedisin (NST). Feltet er ytterligere befolket av ulike finansiører av telemedisinprosjekter; Norges forskningsråd, sosial og helsedirektoratet og helseregionenes forskingsfond. Sitatene over viser at hvor teknisk kapital er akkumulert og hvordan den kan omsettes til en viss grad er uklart for flere av aktørene i feltet. Dette skaper spenninger.

En distriktslege snakket om "duppedittgjengen":

"det som i hvert fall er viktig er at, at telemedisinske løsninger skal være løsninger på et problem som blir definert av enten pasienter eller helsepersonell. Så vi skal gå til duppedittgjengen og så sier vi at «her har vi et problem, kan dere løse eller hjelpe oss?», i motsetning til det som av og til skjer, nemlig at disse her IT/duppedittgjengen kommer til oss og sier «her har vi en kjempefin løsning på et problem som ikke dere har, men som dere bør tro at dere har»"

Vår informant gir uttrykk for at det er feil at "IT/ duppedittgjengen" har fått den posisjon han opplever at de har. Der er altså en kamp om hvem som skal få definere behovene i feltet. Behovene vil avhenge av hva man definerer som den riktige pasientbehandling. Definerer man denne som likeverdig og bærekraftig behandling er telemedisin et godt alternativ. Dersom tilgjengelighet og økonomi ikke regnes som avgjørende av legen, i konkrete behandlingssituasjoner hun står ovenfor, vil ikke telemedisin nødvendigvis forbedre behandlingen. I så fall er ikke IT-utviklere og -leverandørers ideer relevante, og deres nye posisjoner i feltet kan oppleves truende for eksisterende dominante posisjoner; legene.

Vårt empiriske eksempel fra teledermatologi viser detaljene i hvordan de nye IT-aktørenes posisjon i feltet forstyrrer eksisterende maktstrukturer og kan true de tradisjonelt dominante posisjoner. I vårt eksempel var både staten og kliniske praktikere interessert i å inkludere telemedisin i definisjonen av den riktige behandling. Tekniske utfordringer og en beskjed fra IT-avdelingen om økonomien i tjenesten bidro imidlertid til å stanse tilbudet. Eksemplet viser at de nyankomne aktører innen IT-utvikling og -drift har oppnådd sterke posisjoner i helsefeltet. "Disse på IT" bidro i praksis til å definere telemedisin ut av den riktige behandling i akkurat dette eksempelet. Hvorvidt dette var deres intensjon eller ikke er ikke det sentrale spørsmålet for vår analyse. Caset eksemplifiserer først og fremst at IT-utviklere, leverandører og driftspersonell i helsefeltet potensielt har stor 
gjennomslagskraft. Videre viser eksemplet at den kulturelle kapital de veksler inn for å oppnå sine posisjoner, er uklar for de dominerende aktørene. For den kliniske praktikeren fremstår IT-utvikling og drift som en black box: Den interne organisering av telemedisin- og IT-arbeid, inkludert kompleksitet rundt aspekter som økonomi og funksjonalitet, er altså ikke synlig for alle aktørene i feltet

Det blir et praktisk spørsmål om disse skal synliggjøres. Det vil kreve at kunnskap og innsikt om teknologien som brukes, den tekniske kapital, blir fordelt annerledes. Selv om de objektive strukturene er gitt, vil enkeltaktører, i kraft av sine posisjoner og sin habitus, ha ulikt handlerom og gjennomslagskraft i helsefeltet. Vi registrerer at legene som ville ha teledermatologi "stablet på beina igjen" ikke forstod det som sitt ansvar å gripe inn og forfølge eller klage på nedleggingen, eller løse opp i de tekniske utfordringene. Dette er ikke en praksis de går inn, noe som henger sammen med deres habitus; deres skjema for handling som i stor grad er forankret i deres medisinske utdanning. Bruk av andre typer teknologi, for eksempel stetoskopet eller røntgenutstyr er nærmere knyttet til medisiner-habitus og det vi kan kalle de dominante posisjoners definisjon av den riktige behandling. Det er lett å tenke seg at det ville avstedkommet flere protester fra legene dersom sykehusets røntgenutstyr eller stetoskoper ble heftet med "driftsfeil".

\section{Case 2: Telemedisin berøres av de etablerte maktstrukturene i feltet}

Til forskjell fra forrige case er det her ikke snakk om nye aktører som entrer helsefeltet. Prosjektarbeiderne fra NST kan defineres som nye aktører, men det er vår forståelse at de hadde en marginal posisjon. Det vi ønsker å synliggjøre i dette caset er hvordan telemedisin kan forsås som en ny interesse, eller som en ressurs, som inngår i en etablert maktkamp mellom staten og de lokale legene.

Ved lokalsykehuset var de fleste overlegene relativt komfortable med den etablerte behandlingen de gav hjerneslagpasienter. Legene bruker ikke telemedisin. De behandler hjerneslag som tidligere. Sitatene under er hentet fra et gruppeintervju med overleger og sykepleiere ved slagenheten.

Informant 1; Da har vi en bra overlegegruppe her da. Veldig erfarne leger

Informant 2; Folk som har jobbet her i årevis. Snittalder på, midt i femtiårene hele gjengen. De er jo dyktige klinikere, det betyr jo veldig mye. Det er staute karer som jobber her, så 
Informant 1; Ja. Hvis man satt en stor strek over dem, og bare hadde relativt ferske assistentleger og sylferske turnusleger så tror jeg nok det hadde vært, da hadde det gått varmt det derre, det utsyret [teleslag]

Informant 2; Nei, jeg tror vi kan si at de overlegene våre føler seg ganske komfortable i det aller meste som vi får her.

De lokale legenes forklaring på manglende bruk av teleslag var i hovedsak knyttet til at de hadde tilsvarende slagkompetans lokalt som det teleslag kunne bidra med fra distanse. Av totalt seks overleger var en nevrolog, mens de fem andre var spesialister i indremedisin. I tillegg til en solid lokal kompetanse, trakk medisinerne ofte frem betydningen av å ha en "nevrolog på huset", selv om nevrologens tilstedetid var begrenset til hverdager og til dagtid.

Vi ser et spenningsforhold mellom statens klare satsning på telemedisin i behandlingen av hjerneslag, og de lokale legenes manglende bruk av teleslag. Behandling av hjerneslag ved hjelp av telemedisin, kan beskrives som en nyankommen interesse/ressurs, som settes i spill i eksisterende maktkamper i helsefeltet. Helsedepartementet, Helsedirektoratet, Helse Nord og NST er alle statlige institusjoner som promoterer telemedisin generelt, og teleslag spesielt som en ny og effektiv behandlingsform. Det at de lokale legene ikke tar i bruk telemedisin, men forsetter slagbehandlingen som tidligere synligjør at legene ved lokalsykehuset hadde gjennomslagskraft i feltet til å avgjøre hva som er best pasientbehandling.

Det empiriske materialet viser imidlertid at det er mer til saken. Ved lokalsykehuset, var det de samme legene som ikke brukte telemedisin som innførte løsningen, og ikke minst, de ønsket å beholde teleslag til tross for at løsningen ikke ble brukt. Dette kan tolkes på flere måter. Det kan forstås som et utrykk for at legene ser at telemedisin ville være nyttig ved an annen bemanningssituasjon. Noe som sitatene over også antyder. Bourdieus maktperspektiv gjør oss imidlertid sensitive for at det også er andre tolkninger. I en feltanalyse studeres maktrelasjoner. Det å innføre og beholde en behandlingsform som ikke brukes, kan tolkes som et utrykk for at legene utfra et behandlingsperspektiv ikke ønsket teleslag, men at de ikke avskrev telemedisin per se. De offentlige dokumentene vi har studert underbygger en slik tolkning. Dokumentanalyser av helsetilsynets avviksmelding viser at slagbehandlingen ved lokalsykehuset var under press fra helsetilsynet i samme periode som de fikk tilbud om å innføre teleslag. I 2010 mottok sykehuset en melding fra helsetilsynet om at hjerneslagbehandlingen ved sykehuset avvek fra et myndighetskrav i spesialisthelsetjenesteloven $\S 2-2$, j. I avviksmeldingen står det blant annet at; 
Sykehuset har, i strid med gjeldende kliniske anbefalinger, ikke etablert slagenhet, slagteam eller annen koordinert tverrfaglig slagbehandling. Framgangsmåte for behandling av slagpasienter for øvrig er prosedyrefestet i tråd med konsensusanbefalinger, men prosedyren følges ikke systematisk i den kliniske drift.

Ved å vise til nye de nasjonale retningslinjene for slagbehandling pålegger helsetilsynet sykehuset å omorganisere slagbehandlingen. Innføringen av teleslag var ikke et krav i den pålagte omorganiseringen, men tilbudet om å delta i et teleslagnettverk kom tilfeldigvis i samme periode som lokalsykehuset arbeidet med å innfri omstillingskravet fra helsemyndighetene. Det var også helsemyndighetene, representert ved helseforetaket Helse Nord og NST som finansierte og innførte teleslag ved lokalsykehuset.

Det er viktig å presisere at vår tolkning bygger på empiriske observasjoner og analyser av helsemyndighetenes avviksmeldinger og anbefalinger til hjerneslagbehandling. Vi har ikke intervjudata eller dokumenter som tilsier at telemedisin ble brukt som et virkemiddel til å tilfredsstille myndighetskravene fra helsetilsynet. Vi søker heller ikke sykehusets intensjoner bak innføringen av teleslag, å moralisere over riktig eller gal bruk, eller ta stilling til hva som er best pasientbehandling. Vår målsetning er å synliggjøre hvordan telemedisin berøres av pågående maktstrukturer i helsesektoren. I helsefeltet, som i alle andre felter, utkjempes kamper. I dette eksempelet kjempes det om ulike behandlingsformer for hjerneslag. Mens helsemyndighetene er opptatt om økonomi, effektivitet, og at befolkningen får gode og likeverdige helse- og omsorgstjenester, uavhengig av blant annet bosted og økonomi, kjemper legene for etablerte, utprøvde og lokale behandlingsformer.

Legene har tradisjonelt hatt stor makt i helsefeltet (Kjekshus \& Veggeland, 2011). Det er vår tolkning at legenes habitus gjorde dem i stand til å manøvrerer i feltet på en slik måte at de både kunne imøtekomme helsetilsynets krav, og samtidig fortsette slagbehandlingen uten telemedisin. Det vil si, en kombinasjon av objektiv sosial posisjoner som overleger ved et lokalsykehus, og legenes individuelle posisjoner i feltet. Legene er godt voksne, mannlige overleger, som har vært ved sykehuset en årrekke. De har stor innflytelse ved sykehuset og i regionen. "Det er staute karer som jobber her". Legenes posisjon og gjennomslagskraft i feltet kom også til syne under evalueringen av teleslagprosjektet i 2013. Siden frekvensen av teleslagsendingene fra det andre lokalsykehuset var lav, ble det enighet om å fortsette med tradisjonell hjerneslagbehandling i Nord Norge. Teleslag ble nedlagt som tjeneste kort tid etter. 
Når dette er sagt, må vi ikke glemme at disse legene var de samme som takket ja til teleslag, til tross for at de ikke brukte behandlingsformen. Dette kan tolkes som at forståelsen av at helsefeltet trenger IKT, er i ferd med å befeste seg som et doxisk forhold. Det vil si som en selvfølgelighet som det ikke stilles spørsmål ved. Et legitimt spørsmål er derfor om legene i den gitte situasjonen hadde anledning til å takke nei til å innføre teleslag. Vår tolkning er at legenes habitus og tekniske kapital gir dem gjennomslagskraft til å manøvrere i feltet. Legene hadde oversikt, innsikt og kunnskap, ikke bare om den kliniske behandlingen, men også om statlige IKT-føringer. Dette gjorde dem i stand til å omsette telemedisin som en ressurs i en etablert kamp med statsmakten. Bourdieus begreper gir altså oss en ny inngang til feltet, og sensitiverer analysen for hvordan telemedisin berøres av etablerte maktstrukturer som det kan være vanskelig å få øye på i mikroanalyser. I tradisjonell telemedisinlitteratur er bruk og ikke bruk knyttet til klinikken. Vår analyse bidrar til at vi ser konturene av ett nytt felt som delvis overlapper helsefeltet. Et IT/ telemedisinfelt med en egen feltspesifikk kapital, som kan få betydning langt utover den kliniske bruken.

\section{Oppsummering og konklusjon}

Ettersom vår analyse er inspirert av Bourdieus tre faser for feltanalyse har vi fått frem poenger på flere nivåer. Analysen viser hvordan telemedisin inngår i maktkamper mellom profesjonsmakt og statsmakt om definisjonen på den gode pasientbehandling. Dette er en fundamental interesse som utgjør helsefeltets eksistens. Videre har vi fått frem hvordan teknisk kapital har blitt akkumulert og skapt sterke posisjoner for nye aktører i feltet. I praksis vil det si at forutsetningene for å "stable på beina" telemedisinske løsninger har endret seg siden de første utprøvingene i Nord Norge på slutten av 80 tallet. Samtidig som den teknologiske infrastrukturen har blitt bedre, for eksempel gjennom bredbåndsdekningen og etablering av sikkert nasjonalt helsenett, og teknologien har blitt enklere og mer brukervennlig, har det faktisk blitt vanskeligere for engasjerte enkeltleger å igangsette bruk av telemedisin. I dag er det flere aktører og mer komplekse maktstrukturer rundt innføring av telemedisin enn for 20 år siden. Bruk eller ikke-bruk av telemedisin handler altså om mer enn individuelle holdninger hos leger og pasienter. Utbredelsen av telemedisin er knyttet til overordnede maktstrukturer i helsefeltet. På individnivå viser vi at lokale forskjeller i bruk av telemedisin henger sammen med enkeltaktørers posisjonering i forhold til feltets grunnleggende 
maktkamper, inkludert deres habitus. Legenes evne til å samle og omsette teknisk kapital varierer. I vårt eksempel fra teleslag ser vi at legene tar telemedisin i bruk som en viktig ressurs i sin respons til statlige føringer og pålegg. Telemedisin ble ikke brukt i klinisk behandling, men i den lokale utførelsen av maktkampen mellom stat og helseprofesjonelle fikk den nye teknologien betydning. Statsvitere har pekt på hvordan styringsreformer i den norske helsesektoren har endret legenes rolle fra 80-tallet og frem til i dag (Kjekshus \& Veggeland, 2011). I samme periode som telemedisin har oppstått har medisinen gått fra å være en relativt selv-regulert profesjon, til i større grad å bli ett instrument for statlige prioriteringer og reguleringer (ibid). Vår analyse understreker viktigheten av å forstå mottakelsen av telemedisin i sammenheng med andre statlige reformer i helsevesenet.

Vi ser det som en styrke ved vår studie at den er detaljert og praksisnær. Samtidig vil vi understreke at studier av telemedisin i et maktperspektiv i fremtiden bør utvides til å inkludere flere helseprofesjoner enn legene, og flere typer av helseinstitusjoner.

Gjennom våre to casestudier har vi belyst hvordan telemedisin berører eksisterende maktstrukturer; når statens promotering av telemedisin skaper nye posisjoner, som bringer nye aktører inn i helsefeltet, og hvordan telemedisin berøres av maktstrukturene; når teknologien blir "tatt som gissel" i pågående kamper mellom statlige og profesjonsutøveres interesser. Telemedisinske løsninger gir ikke bare nye verktøy for å understøtte eksisterende behandlingspraksis. Den nye teknologien trigger diskusjoner om hva som er den riktige behandling. Utbredelse, likeså mangel på utbredelse av telemedisin, må forstås i lys av denne maktkampen. Telemedisin handler om mye mer enn nye kliniske verktøy, det handler om de fundamentale interesser og verdier i helsefeltet, og kampen om hvem som skal få definere disse.

\section{Referanser}

Audebert, H. (2006). Telestroke: effective networking. The Lancet Neurology, 5(3), 279-282.

Bourdieu, P. (1995). Distinksjonen. Oslo: Pax.

Bourdieu, P. (1999). Logic of Practice. Polity

Bourdieu, P. (2005). The social structures of the economy: Polity.

Bourdieu, P., \& Wacquant, L. J. (1992). An invitation to reflexive sociology: University of Chicago Press.

Desai, N. (2014). 5 Telehealth Tips for National Doctors Day, from http://www.handsontelehealth.com/past-issues/93-5-telehealth-tips-for-national-doctors-day 
Dünnebeil, S., Sunyaev, A., Blohm, I., Leimeister, J. M., \& Krcmar, H. (2012). Determinants of physicians' technology acceptance for e-health in ambulatory care. International Journal of Medical Informatics, 81(11), 746-760.

Halford, S., \& Savage, M. (2010). RECONCEPTUALIZING DIGITAL SOCIAL INEQUALITY. Information, Communication Eamp; Society, 13(7), 937-955. doi: 10.1080/1369118x.2010.499956

Handschu, R., Scibor, M., Willaczek, B., Nückel, M., Heckmann, J. G., Asshoff, D., . . . Schwab, S. (2008). Telemedicine in acute stroke. Journal of neurology, 255(11), 1792-1797.

Haraway, D. J. (2004). The Haraway Reader: Psychology Press.

Helsedepartementet, S. o. (1999). Telemedisin i Norge, status og veien videre. Rapport fra Arbeidsgruppe.

HOD. (2008). Samhandlingsreformen Rett behandling - på rett sted - til rett tid. Oslo: Retrieved from http://www.regjeringen.no/pages/2206374/PDFS/STM200820090047000DDDPDFS. pdf.

Jensen, C. B., \& Winthereik, B. R. (2002). Political and moralising moments: on visions of IT in Danish health care. Information Technology E People, 15(3), 227-241.

Kjekshus, L. E., \& Veggeland, F. (2011). State Regulatory Capacity: Experiences from Public Sector Reforms in Norway. Public Administration, 89(4), 1568-1584.

KS. (2008). IKT i helse og omsorg 2008-2012. KS.

Langstrup Nielsen, H. (2003). The multiplicities of a modest innovation: The introduction of a monitoring technology for asthma treatment in primary care. The EGOS 2003, track 34:" Materialities of Organizing.

Larsen, F., Gjerdrum, E., Obstfelder, A., \& Lundvoll Nilsen, L. (2003). Implementering av telemedisinske tjenester: hemmende og fremmende faktorer. In N. rapport (Ed.).

May, C. (2013). Agency and implementation: Understanding the embedding of healthcare innovations in practice. Social Science Eamp; Medicine, 78(C), 26-33. doi: 10.1016/j.socscimed.2012.11.021

Meyer, B. C., Raman, R., Hemmen, T., Obler, R., Zivin, J. A., Rao, R., . . Lyden, P. D. (2008). Efficacy of site-independent telemedicine in the STRokE DOC trial: a randomised, blinded, prospective study. The Lancet Neurology, 7(9), 787-795.

Mik-Meyer, N., \& Villadsen, K. (2007). Magtens former. Sociologiske perspektiver på statens møte med borgeren. København: Hans Reitzels forlag.

Mort, M., Finch, T., \& May, C. (2009). Making and unmaking telepatients. Science, Technology \& Human Values, 34(1), 9.

Moseng, D. (2000). Teledermatologi-erfaringer fra Nord-Norge. TIDSSKRIFT-NORSKE LAEGEFORENING, 120(16), 1893-1895.

Norum, J., Bergmo, T. S., Holdo, B., Johansen, M. V., Vold, I. N., Sjaaeng, E. E., \& Jacobsen, H. (2007). A tele-obstetric broadband service including ultrasound, videoconferencing and cardiotocogram. A high cost and a low volume of patients. J Telemed Telecare, 13(4), 180-184.

Obstfelder, A., Lotheringthon, A. T., \& Johanessen, L. K. (2013). Regjering av samhandling i helsesektoren IKT-helse som praksisregime og elektronisk timebestilling som styringsteknologi. In A. Tjora \& L. Medby (Eds.), Samhandling for helse kunnskap, kommunikasjon og teknologi i helsetjenesten. Oslo: Gyldendal.

Regjeringen. (2014). Regjeringen.no, from http://www.regjeringen.no/nn/dep/hod. html?id $=421$

Schreurs, N. (2012). Fiasko eller fremtid?, Computerworld. 
Starling, J., \& Foley, S. (2006). From pilot to permanent service: ten years of paediatric telepsychiatry. Journal of Telemedicine and Telecare, 12(suppl 3), 80-82.

Thomson, P. (2012). Field. In M. Grenfell (Ed.), Pierre BOurdieu, Key concepts. Durham: Acumen.

Tjora, A. (2010). Kvalitative forskningsmetoder i praksis [qualitative research methods in practice]. Oslo: Gyldendal Akademisk.

Walter, Z., \& Lopez, M. S. (2008). Physician acceptance of information technologies: Role of perceived threat to professional autonomy. Decision Support Systems, 46(1), 206-215.

Web, N. (2014). Telemed.no, from http://www.telemed.no/definisjon-av-telemedisin.43862-290358.html

Whitten, P., \& Holtz, B. (2008). Provider utilization of telemedicine: the elephant in the room. Telemedicine and e-Health, 14(9), 995-997.

Whitten, P., Holtz, B., \& Nguyen, L. (2010). Keys to a successful and sustainable telemedicine program. International journal of technology assessment in health care, 26(02), 211-216.

Wyatt, J. C., \& Sullivan, F. (2005). ABC of health informatics: eHealth and the future: promise or peril? BMJ: British Medical Journal, 331(7529), 1391.

Zanaboni, P., \& Wootton, R. (2012). Adoption of telemedicine: from pilot stage to routine delivery. BMC medical informatics and decision making, 12(1), 1.

Ziefle, M., Klack, L., Wilkowska, W., \& Holzinger, A. (2013). Acceptance of Telemedical Treatments-A Medical Professional Point of View Human Interface and the Management of Information. Information and Interaction for Health, Safety, Mobility and Complex Environments (pp. 325-334): Springer. 